\title{
Administration of intravenous immunoglobulins for prophylaxis or treatment of infection in preterm infants: meta-analyses
}

\author{
J B Lacy, A Ohlsson
}

\begin{abstract}
Aims-To determine the effectiveness of intravenous immunoglobulin administration to premature infants in the prevention and/or treatment of bacterial infection. Methods-Computer searches of MEDLINE, EMBASE, SCISEARCH and Oxford Database of Perinatal Trials were made. Two independent researchers applied inclusion criteria of: randomised controlled trial; premature and/or low birthweight infant; use of intravenous immunoglobulin; and infection or mortality. Nineteen of 44 identified studies fulfilled these criteria. Study quality was assessed and information on study population, intervention, and outcomes were collected.

Results-Studies were divided into prophylaxis or treatment; results were tabulated for infection, sepsis, and death from all causes. For 17 studies of prophylaxis $(n=5245)$, the relative risk and confidence interval were, for proved infection 0.81 , $0.67-0.97$; for sepsis $0.87,0.66-1.13$; for death from all causes $0 \cdot 85,0 \cdot 64-1 \cdot 14$. Some outcome results were heterogeneous. Two treatment studies showed no reduction in mortality when combined. Conclusions-Routine administration of intravenous immunoglobulin to preterm infants is not recommended.

(Arch Dis Child 1995; 72: F151-F155)
\end{abstract}

Keywords: Intravenous immunoglobulin, infection, meta-analysis, preterm infants.

Perinatal Program,

Department of

Newborn and

Developmental

Paediatrics, and the

University of Toronto

Perinatal Clinical

Epidemiology Unit,

Women's College

Hospital, Toronto,

Canada

J B Lacy

A Ohlsson

Correspondence to:

J B Lacy, PCEU, Women'

College Hospital, 76

Grenville Street, Toronto,

ON, Canada M5S $1 \mathrm{B2}$.

Accepted 7 February 1995 immunoglobulin (IVIG) administration to premature and/or low birthweight infants prevents nosocomial infections and/or improves outcomes in infants with suspected infections.

Several descriptive review articles of the use of immunoglobulins in neonates have been published. These have included several randomised controlled trials, the authors' personal experience with the drug, and/or information about the preparation or dosing regimen. ${ }^{2-5}$ Weisman et al combine the results of several randomised controlled trials using inappropriate statistical methods. ${ }^{6}$ Baley and Fanaroff presented overviews of randomised controlled trials on the administration of IVIG to neonates. ${ }^{7}$ They reviewed seven studies of the prophylactic use of IVIG which reported an outcome of sepsis, and three studies of the use of IVIG for treatment which reported an outcome of death. They concluded that: 'The preliminary data generated in trials of IVIG are promising, but use of this treatment modality still needs to be considered experimental and should only, as yet, be used under study conditions'. As many studies have been published since this review, a new critical overview of the use of IVIG in preterm infants is warranted.

\section{Methods}

We began the search with articles on this topic in our personal files and then searched the reference list of all these and subsequently retrieved articles. This search yielded 34 studies. MEDLINE was searched from 1966 onwards; we identified five additional studies. Next EMBASE (Excerpta Medica online) was searched from 1980. This search identified three additional studies. The Oxford Database of Perinatal Trials (Version 1.3, Disk Issue No 8, Autumn 1992) was also searched. No additional studies were identified. Two additional studies were identified from SCISEARCH (Science Citation Index). The titles (and abstracts when available) in the MEDLINE, EMBASE, and SCISEARCH printouts were reviewed by JBL and AO. Any article that either person felt might meet the inclusion criteria noted below or that either felt should have its reference list searched was retrieved. No attempt was made to locate unpublished studies. Although we are aware of publications bias, ${ }^{8}$ we felt that any search for 
unpublished studies would result in considerable selection bias.

Criteria used to select studies for inclusion in this overview were:

(i) Design: randomised controlled trial with a control group that received a placebo or no intervention;

(ii) Population: premature ( $<37$ weeks) and/or low birthweight $(<2500 \mathrm{~g})$ infants;

(iii) Intervention: IVIG;

(iv) Outcome: bacterial infection and/or mortality.

JBL and AO applied the above criteria separately and had $100 \%$ agreement. Sixteen studies published in full (14 for prophylaxis and two for treatment ${ }^{19-23}$ ) and three abstracts $^{24-26}$ were accepted. Twenty five studies were rejected. (Log of rejected studies available on request from authors.)

An assessment of the quality of the included studies (excluding abstracts) was done independently by JBL and AO using the system developed by T C Chalmers. ${ }^{27}$ This was not done with the assessors blinded to author, institution, journal of publication or results, as both assessors were familiar with most of the studies and the typographical layout of the journals, and would have had knowledge of these even with blinding; and results sections of articles often included methodological information. The Chalmers system uses 31 questions to assess the description of the study population and treatment, blinding, randomisation, statistical methods, withdrawals and side effects. The Fanaroff study had two phases, the first of which was blinded ${ }^{15}$; quality of the study was assessed for each phase separately.

After the independent scoring the two assessors' total scores for each study were compared and yielded an intraclass correlation coefficient of $0 \cdot 98 .{ }^{28}$ The two assessors then together reviewed each question of the Chalmers system for each of the studies and by consensus developed an overall quality score. These consensus scores were used in the subsequent sensitivity analysis. Although it is possible to score 1.0 on the Chalmers system, in our experience most studies usually do not score above $0 \cdot 8 .{ }^{29} 30 \mathrm{~A}$ priori the decision was made to use 0.4 as the cutoff for an adequate quality score.

Data abstraction forms were developed and pilot tested to verify definitions of terms. JBL and AO independently abstracted information on each study and JBL checked for any discrepancies and pooled the results. Data abstraction included whether the study involved prophylaxis or treatment, the time period and geographical location of the study, baseline characteristics of patients, inclusion or exclusion criteria, preparation and dosing regimen of IVIG and placebo (table 1 ).

Information on outcomes and the numbers of affected infants was abstracted. Most studies reported on the total number of infants with proved infection (clinical signs and symptoms in conjunction with positive cultures from normally sterile body fluids). Many studies reported on sepsis (clinical signs and symptoms

Table 1 Study information

\begin{tabular}{|c|c|c|c|c|c|c|c|c|}
\hline Author & Country & $\begin{array}{l}\text { Prophylaxis/ } \\
\text { treatment }\end{array}$ & $\begin{array}{l}\text { Time } \\
\text { period }\end{array}$ & $\begin{array}{l}\text { Birthweight } \\
\text { (g) } T / C\end{array}$ & $\begin{array}{l}\text { Gestational } \\
\text { age (week) }\end{array}$ & $\begin{array}{l}\text { Intravenous immunoglobulin } \\
\text { type/regimen }\end{array}$ & Placebo & $\begin{array}{l}\text { Sample } \\
\text { size } T / C\end{array}$ \\
\hline $\begin{array}{l}\text { Baker } \\
\quad \text { et al }\end{array}$ & US & $\mathbf{P}$ & $07 / 87-12 / 88$ & $\begin{array}{r}500-1750 / \\
500-1750\end{array}$ & Not given & $\begin{array}{l}\text { Gammagard } 500 \mathrm{mg} / \mathrm{kg} 5 \text { infusions: at } \\
\text { entry, } 1 \text { week later, then every } 14 \text { days }\end{array}$ & $\begin{array}{l}5 \% \text { albumin } 0.9 \\
\mathrm{NaCl}\end{array}$ & $287 / 297$ \\
\hline Brussel $^{9}$ & US & $\mathbf{P}$ & $09 / 84-10 / 87$ & $977 / 1043$ & Not given & $\begin{array}{l}\text { Sandoglobulin } 1000 \mathrm{mg} \text { on } 4 \text { of first } 5 \\
\text { days of life, fifth dose on day } 15 \text { to } 21\end{array}$ & Albumin & $61 / 65$ \\
\hline $\begin{array}{l}\text { Chirico } \\
\text { et al }{ }^{10}\end{array}$ & Italy & $\mathbf{P}$ & $01 / 83-07 / 85$ & $1104 / 1157$ & $29.7 / 29.9$ & $\begin{array}{l}\text { Sandoglobulin } 500 \mathrm{mg} / \mathrm{kg} \text { weekly for } 1 \\
\text { month }\end{array}$ & None & $43 / 40$ \\
\hline $\begin{array}{l}\text { Christensen } \\
\text { et al }{ }^{11}\end{array}$ & US & $\mathbf{P}$ & $11 / 86-07 / 87$ & $1130 / 1110$ & $30.6 / 30.7$ & Gammune-N 750 mg/kg 1 infusion & $\begin{array}{l}0.1 \% \text { albumin in } \\
10 \% \text { maltose }\end{array}$ & $10 / 10$ \\
\hline Clapp $_{\text {el }}^{12}$ & US & $\mathbf{P}$ & $11 / 86-08 / 87$ & $1300 / 1300$ & $30 / 31$ & $\begin{array}{l}\text { Sandoglobulin serum IgG maintained at } \\
\text { or near } 700 \mathrm{mg} / \mathrm{dl}\end{array}$ & $6-10 \%$ sucrose & $56 / 59$ \\
\hline $\begin{array}{l}\text { Conway } \\
\text { et al }\end{array}$ & UK & $\mathbf{P}$ & Not given & $1088 / 1043$ & $27.5 / 27.5$ & $\begin{array}{l}\text { Intraglobulin } 200 \mathrm{mg} / \mathrm{kg} \text { in first } 48 \text { hours, } \\
\text { then every } 3 \text { weeks until discharge. If } \\
\text { infection suspected: } 100 \mathrm{mg} / \mathrm{kg} \text { more. } \\
\text { If proved, another } 100 \mathrm{mg} / \mathrm{kg}\end{array}$ & None & $29 / 26$ \\
\hline $\begin{array}{l}\text { Didato } \\
\text { et al }{ }^{14}\end{array}$ & Italy & $\mathbf{P}$ & $06 / 85-12 / 86$ & $1438 / 1478$ & $31 / 29$ & $\begin{array}{l}\text { Gammaglobulin } 500 \mathrm{mg} / \mathrm{kg} \text { weekly until } \\
36 \text { weeks gestational age }\end{array}$ & None & $40 / 40$ \\
\hline $\begin{array}{l}\text { Fanaroff } \\
\text { et al }\end{array}$ & US & $\mathbf{P}$ & $1 / 88-3 / 91$ & $1082 / 1096$ & $28.3 / 28.4$ & $\begin{array}{l}\text { Sandoglobulin } 900 \mathrm{mg} / \mathrm{kg} \text { for birthweight } \\
<1000 \mathrm{~g} 700 \mathrm{mg} / \mathrm{kg} \text { for birthweight } \\
1000-1500 \mathrm{~g}, \text { every } 14 \text { days until } \\
\text { weight of } 1.8 \mathrm{~kg} \text { or discharge }\end{array}$ & $\begin{array}{l}\text { Phase 1: albumin; } \\
\text { phase 2: none }\end{array}$ & $1204 / 1212$ \\
\hline $\begin{array}{l}\text { Haque } \\
\text { et al }\end{array}$ & $\begin{array}{l}\text { Saudi } \\
\text { Arabia }\end{array}$ & $\mathbf{P}$ & Not given & $1150 / 1100$ & $32.4 / 33$ & $\begin{array}{l}\text { Intraglobulin A: } 120 \mathrm{mg} / \mathrm{kg} \text { day } 1 ; \mathrm{B}: 120 \\
\mathrm{mg} / \mathrm{kg} \text { days } 1,8\end{array}$ & None & $100 / 50$ \\
\hline $\begin{array}{l}\text { Haque } \\
\text { et al } 16\end{array}$ & $\begin{array}{l}\text { Saudi } \\
\text { Arabia }\end{array}$ & $\mathrm{T}$ & (6 months) & $1320 / 1480$ & $33.4 / 35$ & Pentaglobulin $190 \mathrm{mg} / \mathrm{kg} /$ day for 4 days & $10 \%$ dextrose & $30 / 30$ \\
\hline $\begin{array}{l}\text { Kacet } \\
\text { et al }\end{array}$ & France & $\mathbf{P}$ & Not given & $1363 / 1354$ & $30.2 / 30.3$ & $\begin{array}{l}500 \mathrm{mg} / \mathrm{kg} \text { first day of life then weekly } \\
\text { until } 35 \text { weeks }\end{array}$ & None & $96 / 93$ \\
\hline Magny $_{\text {et al }}{ }^{18}$ & France & $\mathbf{P}$ & $87-89$ & Not given & $29.6 / 29.9$ & $\begin{array}{l}\text { Polyvalent IgG } 500 \mathrm{mg}(10 \mathrm{ml}) \text { days } 0,1 \text {, } \\
\quad 2,3,17,31\end{array}$ & $0 \cdot 2 \%$ albumin & $120 / 115$ \\
\hline Malik & US & $\mathbf{P}$ & Not given & Not given & Not given & $\begin{array}{l}\text { Sandoglobulin } 500 \mathrm{mg} / \mathrm{kg} \text { weekly for } 4 \\
\text { months, } 200 \mathrm{mg} / \mathrm{kg} \text { for up to } 6 \text { months }\end{array}$ & None & $15 / 15$ \\
\hline $\begin{array}{l}\text { Ratrisawadi } \\
\text { et al }{ }^{19}\end{array}$ & Thailand & $\mathbf{P}$ & $02 / 88-03 / 90$ & $1321 / 1290$ & $31.3 / 31.0$ & $\begin{array}{l}\text { Biotest Pharma Group 1: } 250 \mathrm{mg} / \mathrm{kg} \text {; } \\
\text { Group 2: } 500 \mathrm{mg} / \mathrm{kg} 1 \text { infusion within } \\
4 \text { hours }\end{array}$ & None & $68 / 34$ \\
\hline $\begin{array}{l}\text { Spady } \\
\text { et al }\end{array}$ & Canada & $\mathbf{P}$ & Not given & Not given & Not given & $\begin{array}{l}300 \mathrm{mg} / \mathrm{kg} \text { at } 24-72 \text { hours of age and } 72 \\
\text { hours later }\end{array}$ & $5 \%$ dextrose & $54 / 57$ \\
\hline $\begin{array}{l}\text { Stabile } \\
\quad \text { et al }\end{array}$ & Italy & $\mathbf{P}$ & $05 / 84-06 / 86$ & Not given & Not given & $\begin{array}{l}\text { Venogamma Polivante } 500 \mathrm{mg} / \mathrm{kg} \text { on } \\
\text { days } 1,2,3,7,14,21,28\end{array}$ & None & $40 / 40$ \\
\hline $\begin{array}{l}\text { van Overmeire } \\
\text { et } \text { al }^{21}\end{array}$ & Belgium & $\mathbf{P}$ & Not given & $1150 / 1120$ & 29.6/29.2 & $\begin{array}{l}\text { Sandoglobulin } 500 \mathrm{mg} / \mathrm{kg} \text { on days } 1,2 \text {, } \\
\quad 3,4,5,6,7,14,21,28\end{array}$ & None & $56 / 60$ \\
\hline $\begin{array}{l}\text { Weisman } \\
\text { et al } 22\end{array}$ & US & $\mathbf{T}$ & $06 / 85-04 / 89$ & Not given & Not given & Sandoglobulin $500 \mathrm{mg} / \mathrm{kg} 1$ infusion & $\begin{array}{l}\text { Albumin } 5 \% \\
\text { sucrose }\end{array}$ & $14 / 17$ \\
\hline $\begin{array}{l}\text { Weisman } \\
\text { et al }\end{array}$ & US & $\mathbf{P}$ & $06 / 85-04 / 89$ & $1251 / 1251$ & 29.6/29.5 & Sandoglobulin $500 \mathrm{mg} / \mathrm{kg} 1$ infusion & $\begin{array}{l}\text { Albumin } 5 \% \\
\text { sucrose }\end{array}$ & $372 / 381$ \\
\hline
\end{tabular}

$\mathrm{T}=$ treatment $\mathbf{C}=$ control; $\mathrm{P}=$ prophylaxis. 


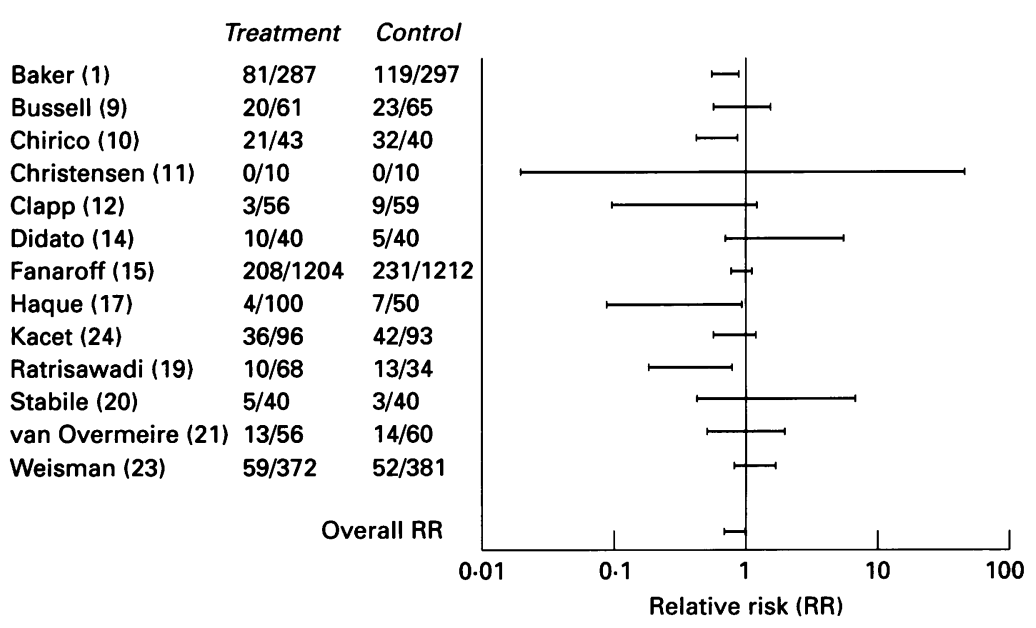

Figure 1 IVIG prophylaxis: effect on infection.

plus positive blood culture), necrotising enterocolitis, death from all causes, and deaths from infection. A few studies reported on length of hospital stay, ventilation, and incidence of bronchopulmonary dysplasia (BPD) and intraventricular haemorrhage (IVH).

\section{STATISTICAL ANALYSIS}

The Statistical Analysis System was used to calculate relative risk (RR) and $95 \%$ confidence intervals (CI). Due to substantial interstudy variability for the prophylactic use of IVIG, a random effects model was used. ${ }^{31}$ For the analysis of treatment with IVIG, a fixed effects model was used. ${ }^{32}$ To test for homogeneity, a Q-statistic was used for the random effects model and the Breslow-Day test was used for the fixed effects model. ${ }^{33} 34$ The primary analysis for the use of IVIG for prophylaxis included all 17 studies. ${ }^{19-15}$ 17-21 23-26 A secondary analysis excluded studies with low quality score $(<0.40)$ and studies that were published as abstracts (in which quality could not be assessed). ${ }^{10} 1317$ 19-21 24-26 The decision to analyse data in this manner was made a priori.

\section{Results}

PROPHYLAXIS

Figures 1 and 2 depict the individual study, outcome data, and typical RR for the outcomes

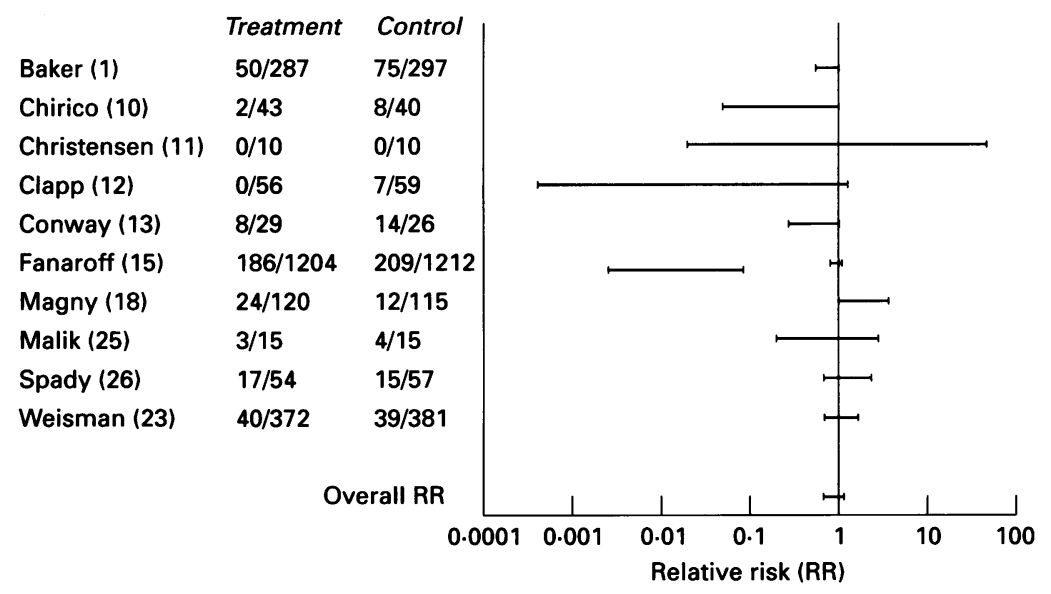

Figure 2 IVIG prophylaxis: effect on sepsis. of proved infection and sepsis for all studies that reported those outcomes. Tables 2 and 3 list the RR and $95 \%$ CIs and the probability of the Q-statistic for homogeneity of the odds ratios for each of the five outcomes (proved infection, sepsis, necrotising enterocolitis, death from all causes, death from infection) of the two analyses.

When all the studies were included (table 2) for the outcome of proved infection, the RR of 0.81 , CI $0.67-0.97$ was significant. For all studies combined, there was no significant difference in sepsis, necrotising enterocolitis, death from all causes and death from infection.

The test from homogeneity indicated that the results for proved infection, sepsis, and necrotising enterocolitis across studies were heterogenous and according to this test, combining the results is inappropriate. When looking for differences among the studies (to explain the heterogeneity), we found that the birthweights and gestational ages of patients were essentially the same. Both placebo controlled and non placebo-controlled studies demonstrated positive results. Although the amount of IVIG varied from $\leqslant 200 \mathrm{mg} / \mathrm{kg}$ to $1000 \mathrm{mg} / \mathrm{kg}$, and from one to more than four total doses, there were studies that demonstrated no benefit from IVIG and others that demonstrated benefit which used smaller or larger amounts and doses. Therefore, the population, intervention, and methodology of the studies were unlikely to be the cause of the heterogeneity of the results.

In the primary analyses in which there was heterogeneity for the results of proved infection, sepsis, and necrotising enterocolitis, there was homogeneity for the outcome results of death from all causes and death from infection. The variable way in which investigators measured the outcomes of proved infection, sepsis, and necrotising enterocolitis was probably responsible for the heterogeneity. When we examined the event rate of the various outcomes in the control groups of the studies in this overview we found an event rate for proved infection that ranged from 0 to $75 \%$ and an event rate for sepsis that ranged from 0 to $54 \%$. The event rate for death from all causes was the least variable with a range of 4 to $33 \%$. A high rate of proved infection or sepsis was generally not associated with a high rate of mortality.

In the secondary analyses (table 3) none of the outcomes was significantly reduced. These results for proved infection, necrotising enterocolitis, death from all causes and death from infection were homogenous; the results for sepsis were heterogenous.

Table 2 Summary of results of all studies for IVIG prophylaxis for neonatal infection ${ }^{19-15}$ 17-21 23-26

\begin{tabular}{lll}
\hline Outcome & $\begin{array}{l}\text { Relative risk } \\
(95 \% \text { CI })\end{array}$ & $\begin{array}{l}\text { Test for } \\
\text { homogeneity }\end{array}$ \\
\hline Proved infection & $0 \cdot 81(0 \cdot 67-0.97)$ & 0.02 \\
Sepsis & $0.87(0.66-1 \cdot 13)$ & 0.03 \\
Necrotising enterocolitis & $1 \cdot 15(0.80-1.64)$ & 0.01 \\
Death from all causes & $0 \cdot 85(0.64-1 \cdot 14)$ & 0.28 \\
Death from infection & $1 \cdot 11(0.64-1.94)$ & 0.42
\end{tabular}


Table 3 Summary of results for IVIG prophylaxis for neonatal infection 19111214151823 excluding abstracts and low quality scores ${ }^{1013} 17$ 19-21 24-26

\begin{tabular}{lll}
\hline Outcome & $\begin{array}{l}\text { Relative risk } \\
(95 \% \mathrm{CI})\end{array}$ & $\begin{array}{l}\text { Test for } \\
\text { homogeneity }\end{array}$ \\
\hline Proved infection & $0.90(0 \cdot 72-1 \cdot 11)$ & 0.08 \\
Sepsis & $0.94(0.69-1 \cdot 28)$ & 0.04 \\
Necrotising enterocolitis & $1 \cdot 13(0 \cdot 82-1 \cdot 55)$ & 0.05 \\
Death from all causes & $1.01(0 \cdot 82-1 \cdot 23)$ & 0.82 \\
Death from infection & $1.41(0 \cdot 73-2 \cdot 72)$ & 0.95 \\
\hline
\end{tabular}

Other outcomes that were not found to be significantly different included: length of ventilation, ${ }^{1} 1013-1518$ incidence of BPD, 110131523 and incidence of IVH. ${ }^{1} 12131523$ Many studies measured duration of hospital stay; however, as some reported on mean or median number of days in hospital and some reported on age at discharge, a meta-analysis of this outcome was not possible. Most studies found no difference in duration of hospital stay. ${ }^{11012152124}$ Spady et al reported a significant reduction in mean age at discharge for a subgroup of infants who had sepsis in the treatment group compared with infants with sepsis in the control group. ${ }^{26}$ Conway et al found a decrease in the median age at discharge for treated infants. ${ }^{13}$

\section{TREATMENT}

Only two studies used IVIG for treatment of infants with known infection. Both studies excluded randomly allocated infants with clinically suspected sepsis who later proved not to have positive cultures. Haque et al found no significant reduction in subsequent infection, but found a significant reduction in mortality. ${ }^{16}$ However, when combined with the results of the study by Weisman et al ${ }^{22}$ (who found no reduction in mortality), the $R R$ was $0.38(95 \%$ CI $0 \cdot 12$ to $1 \cdot 19)$. The Breslow-Day test for homogeneity yielded a probability of $0 \cdot 69$, indicating that the results of this outcome were homogenous and could be combined.

\section{SIDE EFFECTS}

In most studies the investigators examined infants closely for possible side effects. Most side effects were transient and included hypotension, tachycardia, and haemolysis. These side effects were felt to be related to too rapid infusion of placebo or immunoglobulins. Spady et al noted a small but significant increase in respiratory rate following the first infusion of IVIG. ${ }^{26}$

\section{Discussion}

Although the populations and interventions among the studies varied, we felt that there was enough similarity in the studies to make the cautious use of meta-analytic techniques appropriate. In the primary analysis of the prophylactic use of IVIG (inclusion of all studies), there was a reduction in proved infection, but not in the secondary analysis (exclusion of studies published only as abstracts or with poor quality scores). In the primary analysis the results were heterogenous; however, in the secondary analysis the results were homogenous.
When poor quality studies and abstracts were excluded, the effect size was reduced. Sepsis, necrotising enterocolitis, death from all causes or death from infection were not significantly reduced in either analyses. We found heterogeneity for many outcomes except mortality in either analysis, and proved infection and necrotising enterocolitis in the secondary analysis.

A reduction in proved infection in the primary analysis was not associated with a reduction in mortality. Using an event rate of $10 \%$ for overall mortality (which was the average event rate for control infants in this overview), a $25 \%$ risk of reduction, an $\alpha$ of $0 \cdot 05$, and a $\beta$ of $0 \cdot 80$, a sample size of 4166 would be needed to show a significant reduction in mortality. The combined sample size for studies that reported on death from all causes in this review was 3837; therefore, the combined sample size did not have the power to detect a significant difference for this outcome.

Fanaroff et al have published the largest study on the prophylactic use of IVIG, with a total sample size of 2416 or $46 \%$ of the total sample size for all the studies of prophylaxis. ${ }^{15}$ Fanaroff et al conducted their study in two phases: phase 1 was blinded; phase 2 was unblinded. For both phases combined there was no overall reduction in proved infection, sepsis, or mortality. We calculated the relative risk separately for each phase of the study; for phase 1 there was a significant reduction in proved infection and sepsis in the treatment group; for phase 2 there was no significant reduction. We questioned whether the lack of blinding in the second phase resulted in biased measurement of the outcomes of proved infection and sepsis. ${ }^{35}$ Fanaroff answered that our statistical analysis of the two phases separately had not accounted for multiple examination of the data and that we had therefore underestimated the width of the confidence interval, and that he felt that the possibility of bias in the latter half of the trial would have been more plausible if the trial had concluded that IVIG prevented nosocomial infections. ${ }^{36}$

The studies in this review used a wide assortment of preparations of IVIG. Weisman et al studied a variety of commercial preparations of IVIG and concluded that 'pathogenspecific opsonic activity of an IVIG is highly variable for several common neonatal pathogens', and 'predominantly dependent on donor pool and not the manufacturing method'. ${ }^{77}$ IVIG preparations used in the reviewed studies may not have contained the necessary antibodies to prevent or treat infection in the preterm infant. New preparations of IVIG with other antibodies or other combinations of antibodies might be effective.

Only two relatively small studies of the use of IVIG for treatment of infants with suspected infection have been published and when the studies were combined there was no reduction in mortality in infants with subsequently proved infection. ${ }^{1622}$

IVIG administration to preterm infants is not associated with serious side effects. Although we found a decreased $R R$ for 
proved infection in the primary analysis, we found no decrease in sepsis or mortality. We conclude that there is no clear evidence that the prophylactic use of IVIG, using current preparations, is beneficial for preterm infants. There is insubstantial evidence of a benefit of IVIG use for preterm infants who are already infected.

This project was supported by the Garfield Weston Foundation. We acknowledge the statistical assistance of Terri Myhr, MSc.

1 Baker CJ, Melish ME, Hall RT, Castro DT, Vasan U, Givner LB, et al. Intravenous immune globulin for the prevention of nosocomial infection in low-birth-weight neonates. N Engl F Med 1992; 327: 213-9.

2 Kliegman RM, Clapp DW. Rational principles for immunoglobulin prophylaxis and therapy for neonatal immunoglobulin prophylaxis and therapy

3 Fischer GW, Weisman LE. Therapeutic intervention of clinical sepsis with intravenous immunoglobulin, white blood cells and antibiotics. Scand F Infect Dis 1990; 73: 17-21.

4 Weisman LE, Cruess DF, Fischer GW. Current status of intravenous immunoglobulin in preventing or treating neonatal bacterial infections. Clin Rev Allergy 1992; 10: 13-28.

5 Irani SF, Wagle SU, Deshpande PG. Role of intravenous immunoglobulin in prevention and treatment of neonatal infection. Indian Pediatr 1991; 28: 443-9.

6 Weisman LE, Cruess DF, Fischer GW. Standard versus hyperimmune intravenous in preventing or treating neo-
natal bacterial infections. Clin Perinatol 1993; 20: 211-24.

7 Baley JE, Fanaroff AA. Neonatal infections, Part 2: Specific infectious diseases and therapies. In: Sinclair J, Bracken infectious diseases and therapies. In: Sinclair J, Bracken MB, eds. Effective care of the newborn

8 Dickersin $K$. The existence of publication bias and risk factors for its occurrence. $\mathscr{F} A M A$ 1990; 263: 1385-9.

9 Bussel JR. Intravenous gammaglobulin in the prophylaxis of late sepsis in very-low-birth-weight infants: preliminary results of a randomized, double-blind, placeo-controlled trial. Rev Infect Dis 1990; 12: S457-62.

10 Chirico G, Rondini G, Plebani A, Chiaro A, Massa M, Ugazio AG. Intravenous gammaglobulin therapy for prophylaxis of infection in high-risk neonates. $¥$ Pediatr 1987 ; 110: 437-42.

11 Christensen RD, Hardman T, Thornton J, Hill HR. A randomized, double-lind placebo-controlled investigation of the safety of intravenous immune globulin administration the safety of intravenous immune globulin adminis

12 Clapp DW, Kleigman RM, Baley JE, Shenker N, Kyllonen K, Fanaroff AA, et al. Use of intravenously administered K, Fanaroff AA, et al. Use of intravenously administered immune globulin to prevent nosocomial sepsis in low
birth weight infants: report of a pilot study. $\mathcal{F}$ Pediatr 1989; 115: $973-8$.

13 Conway SP, Ng PC, Howell D, Macdain B, Gooi HC. Prophylactic intravenous immuno-globulin in preterm infants: a controlled trial. Vox Sang 1990; 59: 6-11.

14 Didato MA, Gioeli R, Prisolisi A. The use of intravenous gamma-globulin for prevention of sepsis in pre-term infants. Helv Paediatrica Acta 1988; 43: 283-94

15 Fanaroff AA, Korones SB, Wright LI, Wright EC, Poland $\mathrm{RL}$, Bauer CB, et al. A controlled trial of intravenous immune globulin to reduce nosocomial infections in very-low-birth-weight infants. $N$ Engl f Med 1994; 330: very-low-birt
16 Haque KN, Zaidi $\dot{M}$, Bahakim H. IgM-enriched intravenous immunoglobulin therapy in neonatal sepsis. $A m \mathcal{J}$ Dis Child 1988; 142: 1293-6.

17 Haque KN, Zaidi MH, Haque SK, Bahakim H, El-Hazmi M, El-Swailam M. Intravenous immunoglobulin for prevention of sepsis in preterm and low birth weight infants. Pediatr Infect Dis 1986; 5: 622-5.

18 Magny J-F, Bremard-Oury C, Brault D, Menguy C, Voyer M, Landais $\mathrm{P}$, et al. Intravenous immunoglobulin therapy for prevention of infection in high-risk premature infants: for prevention of infection in high-risk premature infants: report of a multi-cer

19 Ratrisawadi V, Srisuwanporn T, Puapondh Y. Intravenous immunglobulin prophylaxis for infection in very low birthweight infants. Fournal of the Medical Association of Thailand 1991; 74: 14-8.

20 Stabile A, Sopo M, Romanelli V, Pastore R, Pesaresi MA Intravenous immunoglobulin for prophylaxis of neonata sepsis in premature infants. Arch Dis Child 1988; 63: 441-3.

21 van Overmeire B, Bleyart S, van Reempts PT, van Acker $\mathrm{KJ}$. The use of intravenously administered immunoglobulins in the prevention of severe infections in very low birth weight neonates. Biol Neonat 1993; 64: 110-5.

22 Weisman LE, Stoll BJ, Kueser TJ, Rabio T, Frank G, Heiman HS, et al. Intravenous immune globulin therapy Heiman HS, et al. Intravenous immune globulin therapy for early-onset sepsis

23 Weisman LE, Stoll BJ, Kueser TJ, Rubio TT, Frank CG, Heiman HS, et al. Intravenous immune globulin prophylaxis of late-onset in premature neonates. $\mathcal{F}$ Pediatr 1994; 125: $922-30$

24 Kacet N, Gremillet C, Zaoui C, Pierrat V, Racoussot S, Dubos JP, et al. Prevention of late-onset infections in preterm infants with intravenous gamma-globulin: a randomized clinical trial. Eur f Pediatr 1991; 150: 604 .

25 Malik S, Giacoia GP, West K, Miller G. Intravenous immunoglobulin to prevent infections in infants with immunoglobulin to prevent infections in infants with

26 Spady DW, Pabst HF, Byrnes P. Intravenous immunoglobulin (IVIG) shortens stay for low birth weight infants. Pediatr Res 1994; 35: 304A.

27 Chalmers TC, Smith H Jr, Blackburn B, Silverman B, Schroeder B, Reitman D, et al. A method for assessing the quality of a randomized control trial. Controlled Clin Trials quality of a rand.

28 Strout PE, Fleiss JL. Intraclass correlations: uses in assessing rater reliability. Psychol Bull 1979; 86: 420-8.

29 Ohlsson A. Treatments of preterm premature rupture of the membranes: a meta-analysis. Am f Obstet Gynecol 1989; 160: 890-906.

30 Ohlsson A, Lacy J. Perinatal clinical epidemiology. Curr Opinion Pediatr 1993; 5: 142-9.

31 Der Simonian R, Laird N. Meta-analysis in clinical trials. Controlled Clin Trials 1986; 7: 177-86.

32 Mantel N, Haenszel W. Statistical aspects of the analysis of data from retrospective studies of disease. $¥ N C I 1959 ; 22$ : 719-48.

33 Dubey $S$. Regulatory considerations on meta-analysis, dentrifice studies and multi-center trials. Proceedings of the Biopharmaceutical Section of the American Statistical Association. 1988: 18-21.

34 Breslow NE, Day NE. Statistical methods in cancer research. Geneva: WHO/IARC Scientific Publications No 32, 1980.

35 Lacy JB, Ohlsson A. Intravenous immune globulin to reduce nosocomial infections. $N$ Engl $\mathcal{F}$ Med 1994; 331: 678.

36 Fanaroff $A$. Intravenous immune globulin in reduce nosocomial infections. $N$ Engl 7 Med 1994; 331: 678.

37 Weisman LE, Cruess DF, Fischer GW. Opsonic activity of commercially available standard intravenous immunoglobulin preparations. Pediatr Infect Dis $\mathcal{f}$ 1994; 13: globulin 


\section{LETTERS TO THE EDITOR}

\section{Pitfalls of meta-analysis}

EDITOR,- - The article by Lacy and Ohlsson clearly shows how statistical manipulation of figures can produce differing results from the same basic data. ${ }^{1}$ The authors with their 'cautious use of meta-analysis' find insubstantial evidence of the benefit of IVIG in either prevention or treatment of neonatal sepsis. Using similar data, Weisman $e t a l^{2}$ found the relative risk of infection if IVIG prophylaxis was not given to neonates to be $2 \cdot 6(3 \cdot 2)$ (mean (SD)), and a relative risk of death in infected neonates not treated with IVIG to be $3 \cdot 0$ $(0 \cdot 7)$. The authors explain this difference by suggesting use of inappropriate statistical methods' by Weisman et al.

Lacy and Ohlsson have heavily pruned published data in search of 'good quality' and 'homogeneity'. In the field of IVIG nothing thus far has been homogenous. All the published data - good or poor quality - have not only differed in entry and outcome criteria but also in basic definitions of variables such as the definition of sepsis and mortality from sepsis. Nor have the authors differentiated between mortality from sepsis and that from unrelated causes or weight groups. Babies that weigh 800 $\mathrm{g}$ have a higher mortality from causes other than sepsis than those weighing $2500 \mathrm{~g}$. The authors have also failed to discriminate between studies in which a placebo was used for the control group and studies in which there was no intervention in the control group.

Another bias in this analysis was the uncritical use of the large study by Fanaroff ${ }^{3}$ which accounts for $46 \%$ of the total sample. This study was blinded only in phase I and open in phase II.

As the authors themselves pointed out, the studies differed in dose regimen, duration of treatment, and the IVIG preparation used. However, they fail to point out two crucially important differences between preparations: bioavailability which depends on the method of preparation, ${ }^{4}$ and variability in IgG subclass distribution. IgG subclass distribution in the preparations is of greatest relevance, taking into account the organisms which cause infection in the neonatal period.

Second, Clapp et $a l^{5}$ and ourselves have clearly shown how important it is to attain and maintain serum IgG above at least 400 $\mathrm{mg} / \mathrm{dl}$ to be protective - very few studies report or measure serum IgG, thus making any comparison extremely difficult, if not impossible.

It may make statistical sense to reject studies which are not prospective, blinded, and controlled, but it makes a nonsense to compare studies without taking into consideration the very principles on which the whole concept of IVIG is based. Information such as bioavailability of the product, serum concentrations obtained, and well defined outcome measure are crucial principles missing from this meta-analysis. Any conclusions drawn on this basis are therefore questionable to say the least. No clinician would use a subtherapeutic dose of antibiotic, for example, and expect it to be effective. It is clear, however, that well designed, large studies with appropriate IVIG are required.
K N HAQUE St Helier Hospital, Wrythe Lane, Carshalton, Surrey SM5 $1 A A$

1 Lacy JB, Ohlsson A. Administration of intravenous immunoglobulins for prophylaxis or treatment of infection in preterm infants: metaanalyses. Arch Dis Child 1995; 72: F151-5.

2 Weisman LE, Cruess DF, Fischer GW. Current status of intravenous immunoglobulin in preventing or treating neonatal bacterial infections. Clin Perinatol 1993; 20: 211-24.

3 Fanaroff A, Wright E, Korones S, et al. A controlled trial of prophylactic intravenous immunoglobulins to reduce nosocomial infections in VLBW infants. Ped Res 1992; 31: 202(A).

4 Morell A. Characterization and safety aspects of intravenous immunoglobulin preparations. In: Koch C, ed. Clinical use of intravenous immunoglobulin. Clinical use of intravenous Publishers, 1988: 9-15.

5 Clapp DW, Baley JE, Kliegman RM, et al. Use of intravenously administered immunoglobulin to prevent nosocomial sepsis in low birth weight infants: Report of a pilot study. F Pediatr 1989; 115: 973-8.

\section{Drs Lacy and Ohlsson comment:}

Dr Haque compares our meta-analysis with the review by Weisman et al. In our paper we used generally accepted methods for a systematic overview. ${ }^{1}$ Our statistical synthesis included a different set of data than those of Weisman et al. We stand by our original statement that Weisman et al used inappropriate statistical methods to combine study results that is, they appear to have combined individual study results by using an arithmetic mean of the relative risks, and thus do not account for study variance which depends on sample size and number of outcomes.

To avoid bias, we used explicit criteria for the inclusion of studies and definitions of outcomes. Regarding Dr Haque's criticism of our use of mortality from all causes other than death from sepsis, we believe that the outcome of death from all causes is less subject to bias than disease specific mortality. Feinsten has recently written that: 'An important scientific advance can occur in meta-analysis ... if the outcomes become confined to total deaths, rather than the inconsistencies and occasional fantasies cited as disease-specific causes of death'. ${ }^{2}$

Our use of the random effects model for pooling of data gave less weight to studies with large sample size than if we had used the fixed effects model.

\section{Correction}

Please note that figure 2 of the paper by Lacy and Ohlsson (Arch Dis Child 1995; 72: F151-5) was incorrectly reproduced and should have looked like this:

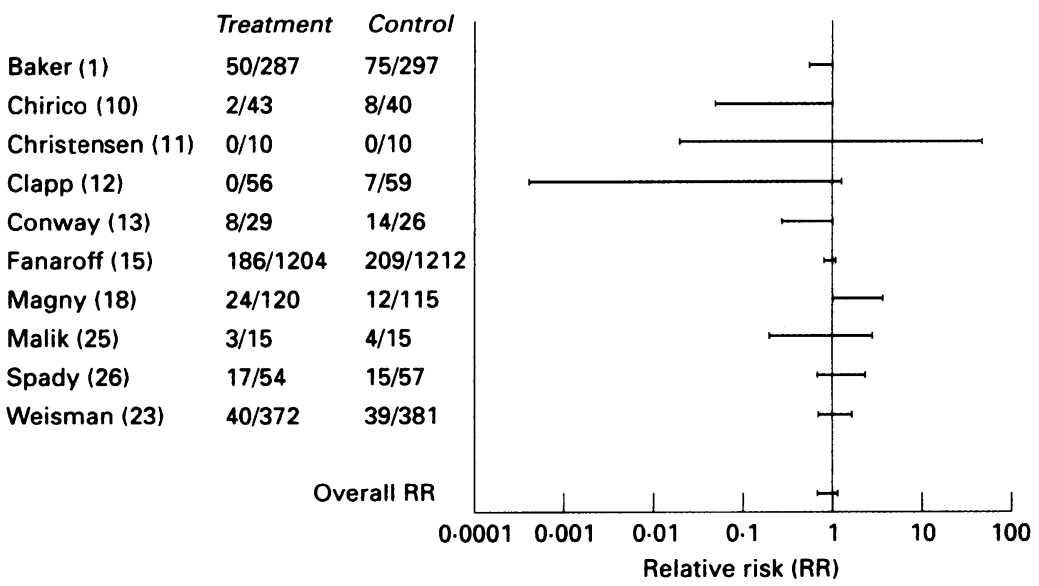

Figure 2 IVIG prophylaxis: effect on sepsis.
In our discussion we emphasised that the lack of benefit for the prophylactic use of IVIG is based on preparations used to date and that 'new preparations of IVIG with other antibodies or other combinations of antibodies might be effective'.

1 Ohlsson A. Systematic reviews - theory and prac-
tice. Scand f Clin Lab Invest 1994; 54 (suppl tice. Scand $\mathcal{F}$

2 Feinstein AR. Meta-analysis: statistical alchemy for the 21 st century. $\mathcal{F}$ Clin Epidemiol 1995; 48: 71-9.

\section{Neonatal meningitis with human parvovirus B19 infection}

EDITOR,-We were interested to read two recent papers by Okumura and Watanabe, on the infection of the central nervous system by human parvovirus B19 (B19) infection. ${ }^{12}$ In these cases, the disease manifest at around school age and not during the neonatal period. Three years ago, we encountered a newborn infant who presented with meningitis and persistent anaemia, presumably related to $\mathrm{B} 19$ infection.

\section{Case report}

A 20 day old girl was admitted with high fever $\left(39 \cdot 8^{\circ} \mathrm{C}\right)$. She had been born by normal vaginal delivery, and showed uneventful growth until poor feeding developed on the 17 th day of life. On the day of admission, the infant's mother had had low grade fever, joint pains, a rash on all four limbs and headache. Both the infant and the mother had had close contact with the infant's 5 year old brother, who had had erythema infectiosum 17 days previously. Her peripheral leucocyte count was $10.2 \times 10^{9} / 1$, erythrocyte count $3.91 \times 10^{12} / \mathrm{l}$, and haemoglobin $127 \mathrm{~g} / \mathrm{l}$. A cerebrospinal fluid (CSF) sample indicated severe pleocytosis $\left(861 \times 10^{3}\right.$ leucocytes $/ \mathrm{ml}$, with $57 \%$ lymphocytes and $43 \%$ neutrophils), along with $23 \times 10^{3} \mathrm{red}$ cells $/ \mathrm{ml}$, protein 0.54 $\mathrm{g} / \mathrm{l}$, and glucose $2 \cdot 7 \mathrm{mmol} / \mathrm{l}$. Serum anti-B19 IgG and IgM tested by enzyme linked immunosorbent assays (SRL commercial assay) were positive in both the infant and the mother. Routine cultures of CSF, blood, and throat swabs yielded no pathogenic growth. Aseptic meningitis were diagnosed, and antibiotics (imipenem, cefotaxime, and amikacin) and gamma globulin were started. Her fever 